The study involved 34 students of Sumy State Pedagogical University named after A. S. Makarenko. The possibility of the influence of a set of exercises for the development of coordination abilities on changes in attention indicators (stability, concentration, intensity, distribution) in students was determined.

The analysis of literature sources, psychological testing of the level of attention parameters, determination of the level of development of students' coordination abilities, the method of mathematical statistics were used.

The analysis of the scientific and methodological literature has shown that a positive background for the adjustment of attention (distribution, intensity, stability, concentration) can create exercises for the development of coordination skills, because such exercises increase the stability of the nervous system.

The study revealed differences between the indicators of students' attention before and after the application of a set of exercises for the development of coordination skills at physical education classes.

During the experiment, it was found out that students with a weak nervous system mastered difficult coordination skills better when the demonstration of actions had been applied. Individuals with a strong type of nervous system are more successful in mastering complex coordination motor actions when using the method of explanation.

It was experimentally confirmed that the use of a set of exercises to develop coordination skills, taking into account the typological features of the students' nervous system, had improved attention.

Key words: attention parameters, coordination abilities, students.

удк 378.091:005.336.2

\author{
Жанна Чернякова \\ Сумський державний педагогічний \\ університет імені А. С. Макаренка \\ ORCID ID 0000-0003-4547-9388 \\ DOI 10.24139/2312-5993/2020.02/183-195
}

\title{
ФОРМУВАННЯ ФІЗКУЛЬТУРНО-ОЗДОРОВЧОЇ КОМПЕТЕНТНОСТІ МАЙБУТНІХ УЧИТЕЛІВ ФІЗИЧНОЇ КУЛЬТУРИ В ПРОЦЕСІ ВИВЧЕННЯ ПЕДАГОГІЧНИХ ДИСЦИПЛІН
}

У статті представлено теоретичний аналіз різних видів компетентностей у складі фрізкультурно-оздоровчої компетентності вчителя фізичної культури залежно від типів профресійної діяльності, сфери прояву та реалізації певних видів компетентності, функцій професійної діяльності. Схарактеризовано три рівні компетентностей 3 використанням дескрипторів «національної рамки квалірікацій» («знання», «уміння», «комунікація» й «автономність та відповідальність»): інтегральні, загальні та спеціальні. Конкретизовано компоненти структури фрізкультурно-оздоровчої компетентності майбутніх учителів фізичної культури в прочесі вивчення педагогічних дисциплін у закладі вищої освіти, зокрема, мотиваційно-ціннісний, змістовий, процесуальний, інформаційний та творчий.

Ключові слова: фрізкультурно-оздоровча компетентність, учителі фізичної культури, інтегральні, загальні та спеціальні компетентності, педагогічні дисципліни, заклад вищої освіти.

Постановка проблеми. Модернізація національної системи освіти, що відображає процес євроінтеграції українського суспільства, потреби ринку 
праці в конкурентоздатних фахівцях, які готові підняти престиж країни в світовій спільноті, зумовлює появу принципово нових підходів до організації освітнього процесу в закладах вищої освіти. Динамізм сучасних освітніх перетворень детермінує потребу підготовки нової генерації вчителів фізичної культури, здатних до виконання педагогічної діяльності на високому професійному рівні.

У реаліях сьогодення освіта $€$ стратегічним ресурсом соціальноекономічного, культурного й духовного розвитку суспільства. На державному рівні Закони «Про освіту» (2017), «Про загальну середню освіту» (2017), «Про затвердження Державної цільової соціальної програми розвитку фізичної культури та спорту на період до 2020 року», Національна стратегія розвитку освіти в Україні на період до 2021 року, Стратегія національно-патріотичного виховання дітей і молоді та інші законодавчі й нормативні документи 3 питань освіти наголошують, що найвищою цінністю суспільства та пріоритетом освітньої політики в Україні $€$ фізична культура та здоров'я нації.

На сучасному етапі фізичне виховання $€$ невід'ємною складовою освіти та спрямоване на формування фізичного, соціального й духовного здоров'я, удосконалення фізичної і психічної підготовки дітей та молоді до активного довготривалого життя й професійної діяльності, а також забезпечує можливість набуття кожною людиною необхідних науково обґрунтованих знань про здоров'я, засоби його зміцнення, організацію змістовного дозвілля тощо. Надзвичайна важливість фізичного виховання актуалізує проблему професійної підготовки вчителів фізичної культури, висуває високі вимоги до їх професійної компетентності, активної самореалізації та саморозвитку.

У процесі викладання педагогічних дисциплін необхідно звернути увагу на вирішення пізнавальних та виховних завдань, а саме розширення світогляду студентів; прищеплення інтересу та звички до занять фізичними вправами; дбайливого ставлення до свого здоров'я; формування стійких мотиваційних установок на здоровий спосіб життя; усвідомлення необхідності розвивати свої фізичні здібності; виховання моральновольових і психологічних якостей особистості.

Аналіз актуальних досліджень. Формування професійної компетентності майбутніх учителів фізичної культури в системі вищої освіти висвітлено в роботах Т. Диби, І. Іванія, А. Коноха, Р. Маслюка, Н. Самсутіної, Л. Сущенко та ін.; теоретично-методичні засади оптимізації професійної підготовки розглянуто в дослідженнях Л. Волошко, І. Гринченка, Ю. Зайцевої, Є. Захаріної, Б. Максимчука, Є. Павлюка, А. Сватьєва та ін.; формування готовності до професійної діяльності досліджено в працях М. Данилко, Н. Степанченко, О. Худолій, О. Шалар, Т. Чопик та ін.; формування складових професійної компетентності висвітлено в роботах О. Стасенко, В. Хоменко, С. Хоменко, В.Чернякова, А. Чорноштан та ін.; формування особистості 
майбутніх учителів фізичної культури в процесі професійної підготовки представлено в дослідженнях Ю. Голенкова, О. Онопрієнко, Б. Шиян та ін.

Проблему формування фізкультурно-оздоровчої компетентності розглянуто в наукових працях Н. Бордовської, С. Занюк, Г. Головченко, Т. Бондаренко та інших. Підґрунтям вивчення проблеми професійної підготовки майбутніх фахівців до фізкультурно-оздоровчої діяльності стали наукові праці О. Андрєєвої, О. Ажиппо, М. Дутчака та ін.

Метою дослідження $€$ теоретичний аналіз та характеристика компонентів структури фізкультурно-оздоровчої компетентності майбутніх учителів фізичної культури в процесі вивчення педагогічних дисциплін у закладі вищої освіти.

Методи дослідження. Окреслена мета дослідження зумовила вибір комплексу взаємопов'язаних методів, зокрема теоретичних: теоретичний аналіз наукової літератури і нормативних документів, синтез, порівняння, узагальнення й систематизація одержаних даних із метою визначення змісту та структури фізкультурно-оздоровчої компетентності майбутніх учителів фізичної культури в процесі вивчення педагогічних дисциплін.

Виклад основного матеріалу. Майбутній фахівець повинен отримати не тільки сукупність знань, умінь та навичок у закладах вищої освіти, а також навчитися застосовувати їх у подальшій професійній діяльності та розв'язувати завдання повсякденного життя. Тому сучасні вимоги висуваються як до студентів, так і до професорсько-викладацького складу: сформувати новий тип особистості майбутнього спеціаліста.

У процесі викладання педагогічних дисциплін необхідно сформувати фізкультурно-оздоровчу компетентність майбутніх учителів фізичної культури з метою виконання власної професійної діяльності. На думку С. Гуменюк, існує декілька актуальних проблем підготовки майбутніх учителів фізичної культури, зокрема, професійно-педагогічна підготовка, психолого-педагогічні основи майстерності вчителя, викладання окремих педагогічних дисциплін у структурі підготовки майбутніх учителів фізичної культури, підготовка майбутніх учителів до творчо-пошукової діяльності; застосування інформаційно-комунікативних технологій у підготовці майбутніх учителів фізичної культури; використання різноманітних інноваційних методів, засобів навчання в процесі фахової підготовки (Гуменюк, 2015, с. 5-6).

Зауважимо, що рівень розвитку фізкультурно-оздоровчої компетентності визначається здатністю й готовністю майбутніх учителів фізичної культури до виконання функцій професійної діяльності. Фізкультурно-оздоровча компетентність викладача як інтегративне утворення являє собою комплекс різних видів компетентностей, що відбивають складну природу його педагогічної діяльності.

Так, основними характеристиками фізкультурно-оздоровчої компетентності майбутніх учителів фізичної культури у процесі вивчення 
педагогічних дисциплін є: особистісно-гуманна орієнтація; здатність до системного бачення педагогічної реальності у сфері фізичної культури й системних дій у професійно-педагогічній діяльності; володіння сучасними педагогічними методиками та технологіями, пов'язаними з культурою комунікації, взаємодії з інформацією та ії передачі учням; здатність до інтеграції вітчизняного, зарубіжного, історичного й сучасного інноваційного педагогічного та фізкультурно-оздоровчого досвіду; використання творчого підходу до розв'язання педагогічних ситуацій у професійній сфері; наявність рефлексивної культури майбутнього вчителя (Іваній, 2013, с. 45).

Порівняльний аналіз педагогічної та методичної літератури дозволив з'ясувати, що дослідниками визначаються різні види компетентностей у складі фізкультурно-оздоровчої компетентності вчителя фізичної культури залежно від типів професійної діяльності, сфери прояву та реалізації певних видів компетентності, функцій професійної діяльності.

Так, на думку О. Омельяненко, ключові компетентності вчителя фізичної культури залежно від сфери прояву та реалізації складають: здатність до саморозвитку й самоосвіти, адаптивності та мобільності, творчої діяльності, дослідництва, інтеграції різноманітних педагогічних компетентностей, здатність виокремлювати індивідуальні цінності на основі соціальних і державних пріоритетів та орієнтувати на них свою професійну діяльність (Омельяненко, 2006, с. 117-118).

У той самий час за видами професійної діяльності О. Онопрієнко визначає такі базові компетентності вчителів фізичної культури: професійнодіяльнісний компонент (предметно-теоретична, інформаційно-дослідницька, методична компетентність); комунікативний компонент (компетентність професійного спілкування та соціокультурна); особистісний компонент (прагнення до досконалості в професійній діяльності й адекватна ії самооцінка, рефлексивна та творча компетентність) (Онопрієнко, 2009).

Проте в сучасних наукових дослідженнях немає загальноприйнятої структури фізкультурно-оздоровчої компетентності майбутніх учителів. Наукові розвідки дослідників не обмежуються переліком компетентностей у пошуку визначення ієрархії, структури та взаємозв'язків фізкультурнооздоровчої компетентності.

Так, у наукових працях С. Скворцова пов'язує структуру професійної компетентності майбутніх учителів зі структурою педагогічної діяльності та виокремлює такі взаємопов'язані компоненти в першій:

- праксеологічний (професійні знання і професійні вміння);

- гносеологічний (сприйнятт, осмислення й відображення інформації, пізнання та конструювання дидактичного процесу);

- аксіологічний (професійні позиції, установки, цінності, професійна позиція вчителя);

- соціальний (спільна діяльність вчителя й учнів); 
- комунікативний (процес взаємодії учасників педагогічного процесу);

- особистісний (професійно необхідні якості вчителя);

- творчий (креативність професійної праці вчителя);

- рефлексивний (адекватна оцінка процесу і результату своєї діяльності, власних професійних можливостей, здатність подолання професійних криз та професійних деформацій, прагнення до досконалості у професійній діяльності);

- соціокультурний (сполучення в соціальному контексті професійної діяльності потреб у національній ідентичності та транснаціональної свідомості в межах єдиного європейського простору) (Скворцова, 2011).

Зазначені вище компоненти дослідниця С. Скворцова об'єднує в три блоки, зокрема: професійно-діяльнісний (праксеологічний, гносеологічний, аксіологічний, соціальний); комунікативний (комунікативний, соціокультурний); особистісний (особистісний, творчий, рефлексивний).

У контексті нашого дослідження важливим $€$ звернення до аналізу трирівневої ієрархії професійної компетентності, запропонованої В. Сидоренко. Кожен представлений рівень здійснюється у сфері професійно-педагогічної діяльності, професійно-педагогічного спілкування та у сфері реалізації особистості.

До першого рівня належать метакомпетентності або метапредметні компетентності (key competences), що $є$ іï ключовими, надпредметними, поліфункціональними, інваріантними структурними компонентами, які складають суспільно визначений комплекс універсальних знань, умінь, ставлень, цінностей для компетентного вирішення міжпредметної низки проблем, забезпечують професійний розвиток фахівця, дають змогу ефективно брати участь у багатьох соціальних сферах та сприяють особистісному успіху.

Другий рівень включає предметні компетентності (subject competences), що характеризують професійно-педагогічну діяльність сучасного фахівця та охоплюють професійно значущі предметні навички, необхідні для кваліфікованого виконання професійних ролей та функцій відповідно до суспільних і освітніх викликів.

Третій рівень охоплює професійні компетентності (professional competences), тобто здатності, властивості, важливі для ефективного виконання роботи на відповідній позиції, які ґрунтуються на знаннях, здібностях, досвіді й цінностях особистості (Сидоренко, 2017, с. 10-15).

Наголосимо, що вітчизняні науковці, насамперед, Н. Бібік, Г. Єльникова, І. Єрмаков, О. Зайченко, В. Маслов, І. Мінтій, О. Овчарук, Н. Радіонова, А. Тряпіцина та інші поділяють свої наукові погляди щодо існування трирівневої структури професійної компетентності вчителя. Наприклад, певним чином відбувається лише варіювання назви цих компонентів, зокрема: 
1) ключові компетентності (необхідні для будь-якої діяльності). У наукових дослідженнях ключові компетентності вчителя трактуються як сукупність різних видів компетентностей, наприклад:

- особистісної, соціальної, предметної та стратегічної (Сидоренко, 2017);

- інформаційної, соціально-психологічної, громадянської, комунікативної, методологічної, життєвої, професійної, психологічної (рефлексивної) (Компетентнісний підхід у сучасній освіті: світовий досвід та українські перспективи, 2004; Кострікін, 2013);

- громадянської, загальнокультурної, здоров'язбережувальної, інформаційної компетентностей та компетентності цілеспрямованого саморозвитку (Драч, 2014).

2) базові компетентності (загальнофахові, загальнопрофесійні) належать до певної категорії - сукупності фахівців, поєднаних одним предметом діяльності. Вони $€$ відображенням специфіки професійної діяльності педагога й одночасно реалізують ключові компетентності.

Зміст базових компетентностей вітчизняні вчені розглядають як єдність різних видів компетентностей, а саме:

- інформаційної, предметної й міжпредметної, психологопедагогічної та науково-методичної компетентностей; а також конструктивно-технологічної, рефлексивно-педагогічної, кваліметричної, креативної компетентностей (Іваній, 2013);

- психолого-педагогічної, науково-дослідницької компетентностей та компетентності з педагогічного менеджменту (Драч, 2014);

- предметно-теоретичної, інформаційно-дослідницької, методичної, професійного спілкування, соціокультурної, творчої, рефлексивної (Процко, 2009).

3) спеціальні (спеціально-фахові) компетентності, що відображають специфіку конкретної дисципліни, яку викладає вчитель.

Відповідно до Методичних рекомендацій щодо розроблення стандартів вищої освіти (2016), затверджених наказом Міністерства освіти і науки України (Омельяненко, 2006), визначається три рівні компетентностей із використанням дескрипторів «Національної рамки кваліфікацій» («знання», «уміння», «комунікація» і «автономність та відповідальність»):

1) інтегральна компетентність являє собою узагальнений опис кваліфікаційного рівня, що виражає основні компетентнісні характеристики рівня щодо навчання та/або професійної діяльності. За її основу взято опис відповідного кваліфікаційного рівня Національної рамки кваліфікацій;

2) загальні компетентності $€$ універсальними компетентностями, що не залежать від предметної сфери, але важливі для успішної подальшої професійної та соціальної діяльності здобувача в різних галузях та для його 
особистісного розвитку. Їх перелік нараховує до 5-15 компетентностей, які рекомендовано обирати з переліку проекту TUNING;

3) спеціальні (фахові, предметні) компетентності - це компетентності, що залежать від предметної сфери, та $є$ важливими для успішної професійної діяльності за певною спеціальністю. Це 10-20 компетентностей, що рекомендовано обирати з переліків проекту TUNING (які, проте, не є вичерпними).

У контексті нашого дослідження ми будемо спиратися на останній зазначений підхід та виокремлювати в її структурі такі компетентності:

- інтегральні компетентності (здатність розв'язувати складні задачі та практичні проблеми у певній галузі професійної діяльності, що передбачає застосування теоретичних знань, умінь та навичок, методів, засобів педагогічних та спеціалізованих дисциплін);

- загальні компетентності (знання, навички та здатності, якими студент оволодіває в межах виконання певної програми навчання, що мають універсальний характер);

- спеціальні компетентності, специфічні для предметної та безпосередньо пов'язані із спеціальними знаннями у ній, що визначають профіль програми, тобто роблять їі індивідуальною, істотно відмінною від інших програм (Кравченко, 2016, с. 289-290).

Ураховуючи зазначене вище нами конкретизовано компоненти структури фізкультурно-оздоровчої компетентності майбутніх учителів у процесі вивчення педагогічних дисциплін у закладі вищої освіти:

1) мотиваційно-ціннісний компонент, рушійною силою якого $\epsilon$ мотивація. Вона містить такі види спонукань: мотиви, потреби, інтереси, прагнення, цілі, ідеали тощо. Потреби майбутнього вчителя полягають у постійному самовдосконаленні, саморозвиткові та творчій самореалізації. Мотивація детермінується зовнішніми умовами (умовами зовнішнього середовища для задоволення потреби) та внутрішніми чинниками, які представляють систему потреб і мотивів, зумовлених особистісними цінностями суб'єкта, й визначають особистісний сенс діяльності.

На нашу думку, до найбільш важливих видів мотивації для досягнення високих результатів можна віднести:

- мотивацію досягнення, яка зорієнтована на мету та певний результат, який можна досягти завдяки власним здібностям;

- мотивацію самоствердження, що виявляється у прагненні студента ствердити себе в соціумі;

- мотивацію ідентифікації з іншою особистістю, яка виявляється у прагненні наслідувати кумира, авторитетну особистість;

- мотивацію саморозвитку, що виявляється в прагненні до самовдосконалення, найбільш повної реалізації своїх здібностей та бажання відчувати свою компетентність;

- мотивацію самооцінки себе як майбутнього професіонала. 
Отже, мотиваційний компонент відображає сформовану потребу в накопиченні системи педагогічних та спеціальних знань, умінь та навичок, мотивів і переконань, що організовують і спрямовують вольові зусилля, а також пізнавальну і практичну діяльність із залученням студентів до ведення здорового способу життя, фізичного вдосконалення.

У той самий час $Є$. Клімов вважає, що система ціннісних орієнтацій $є$ притаманною для кожної професійної групи. Ціннісні орієнтації зумовлюють професійну поведінку, забезпечують зміст і спрямованість діяльності та надають сенс професійним діям. Ціннісні орієнтації $€$ стратегічним орієнтиром у житті, у тому числі й у професії кожної людини (Климов, 1996).

Науковець Г. Безверхня наголошує, що структура ціннісних орієнтацій особистості виступає в ролі системи, яка визначає мотивацію поведінки особистості в професійній сфері (Безверхня, 2003). На думку О. Кострікіна, сукупність ціннісних орієнтацій зумовлює змістовну складову спрямованості особистості та є основою світосприйняття людини, мотивації життєвої активності та вибору професійного шляху, відіграє значущу роль у взаєминах із іншими людьми та навколишнім світом (Кострікін, 2013).

Таким чином, мотиваційно-ціннісний компонент, що входить до складу структури фізкультурно-оздоровчої компетентності майбутніх учителів, передбачає наявність мотивів щодо отримання вищої фізкультурної освіти; переконання щодо значущості соціокультурної місії фахівців з фізичного виховання та спорту; стійкого позитивного ставлення до професії в галузі фізичної культури і спорту; ціннісних орієнтацій як основи життєвої активності та вибору професійного шляху; професійної мотивації, що враховує сукупність потреб та інтересів, які спонукають студентів до професійної самореалізації та професійного вдосконалення у фізкультурно-оздоровчої діяльності; професійної спрямованості на ефективне виконання завдань фізкультурно-оздоровчої діяльності.

Змістовий компонент (система професійно необхідних знань, пізнавальних умінь та навичок для ефективного виконання професійних функцій). Професійно необхідними є педагогічні, психологічні, методичні, анатомо-фізіологічні знання, а також знання з безпеки життєдіяльності та проблем фізичної культури та спорту.

Процесуальний компонент у структурі фізкультурно-оздоровчої компетентності майбутніх учителів є компонентом готовності, як зазначає Л. Сущенко, та потребує перетворення знань: з одного боку, знання повинні бути синтезованими та об'єднаними навколо певної проблеми, яка має різноманітний та цілісний характер, а з іншого боку, - вони повинні бути переведені на мову практичних дій, практичних ситуацій, тобто виступити засобом вирішення реальних практичних завдань (Сущенко, 2003).

Отже, у процесуальному компоненті готовності майбутніх фахівців із фізичного виховання та спорту знаходять місце вміння та навички успішно 
виконувати професійно-педагогічну та фізкультурно-оздоровчу діяльність, індивідуальний стиль застосовування методів і засобів фізкультурнооздоровчої діяльності; уміння проектувати, планувати та здійснювати рекреаційно-оздоровчу діяльність із урахуванням сучасних інноваційних педагогічних технологій.

Інформаційний компонент (самостійне обрання студентом активної життєвої позиції, спрямованої на збереження й закріплення власного здоров'я через збільшення обсягу знань, умінь і навичок в організації самостійного рухового режиму). Студенти самостійно одержують інформацію про збереження й зміцнення здоров'я з різних джерел, що дозволяє їм творчо розв'язувати практичні завдання.

5. Творчий компонент (практичне використання засвоєних теоретичних знань у стандартних і нестандартних життєвих ситуаціях з використанням новітніх інноваційних педагогічних та оздоровчих технологій).

Проблема формування фізкультурно-оздоровчої компетентності майбутніх учителів у процесі професійної підготовки $є$ актуальною для сучасного суспільства, адже наявність або відсутність цієї готовності визначає, чи буде випускник працювати після закінчення закладу вищої освіти. Майбутні спеціалісти, перш за все, з'ясовують для себе сутність подальшого професійного самовизначення, цілі професійного саморозвитку та самореалізації в обраній сфері.

Ми вважаємо, що формування фізкультурно-оздоровчої компетентності майбутніх учителів у процесі вивчення педагогічних дисциплін, а саме «Педагогіки», «Історії педагогіки», «Порівняльної педагогіки» ефективно відбувається за рахунок поєднання теоретичних знань та практичної діяльності.

Під час вивчення педагогічних дисциплін студентам пропонуються такі форми занять: лекції із застосуванням мультимедійних засобів навчання та елементами проблемного навчання; практичні заняття, що включають обговорення теоретичних та практичних питань із запропонованої теми, самосійну роботу з літературними джерелами (аналіз, реферування наукових статей, складання тез, підготовка повідомлень, доповідей), науково-дослідну студентську роботу, що розширює сферу пошукової діяльності в напрямі оздоровчої фізичної культури та всебічного розвитку особистості.

Особлива увагу приділяється підвищенню мотивації студентів до вивчення педагогічних дисциплін, оскільки відбувається засвоєння теоретичних знань та набуття вмінь і навичок, необхідних для розв'язання практичних завдань фізкультурно-оздоровчої роботи. Наприклад, вивчення курсу «Педагогіка» надає студентам можливість оволодіти практичними вміннями та підготуватися до педагогічної практики як учителя-предметника, так і класного керівника. Студенти мають можливість самостійно підготувати і 
провести фрагмент виховного заходу з фізичної культури із застосуванням інноваційних форм виховної роботи. Студентами групи обговорюються переваги, недоліки виховного заходу, надаються доцільні рекомендації щодо покращення діяльності студента, у свою чергу, студент аналізує власну педагогічну діяльність із метою ії оцінювання. У подальшому процесі вивчення педагогічних дисциплін відбувається поступова підготовка студентів до педагогічної практики в закладах загальної середньої освіти. Саме оволодіння загальними навичками майбутньої професійної діяльності відбувається через набуття вмінь здійснювати наукові дослідження, застосування творчих умінь щодо розв'язання педагогічних ситуацій, трансформацію теоретико-методичних знань у власний професійний досвід, умінь самостійно розвиватися й самовдосконалюватися.

Формування фізкультурно-оздоровчої компетентності майбутніх учителів передбачає використання як традиційних (інструктаж, консультація, індивідуальна бесіда; обговорення уроків, позаурочних заходів; самостійна робота з джерелами науково-методичної, психолого-педагогічної інформації тощо), так і інноваційних форм роботи (скайп-конференції, засоби мобільного зв'язку, синхронне та асинхронне використання електронної пошти, чатів, програм-месенджерів, форумів, сторінок у соціальних мережах, підготовку відео- та фотоматеріалів для звітної документації тощо).

Таким чином, формування фізкультурно-оздоровчої компетентності майбутніх учителів фізичної культури $€$ основою готовності педагога до вирішення професійно-педагогічних завдань із фізкультурно-оздоровчої діяльності.

Висновки та перспективи подальших наукових розвідок. Проведене теоретичне дослідження надало можливість проаналізувати й схарактеризувати структуру фізкультурно-оздоровчої компетентності майбутніх учителів фізичної культури у процесі вивчення педагогічних дисциплін у закладі вищої освіти. Доведено, що сутність поняття «фізкультурно-оздоровча компетентність» трактується як сукупність різних видів компетентностей (елементів), що входять до ії складу та відображають різні аспекти та функції фізкультурно-оздоровчої діяльності. Конкретизовано компоненти структури фізкультурно-оздоровчої компетентності майбутніх учителів у процесі вивчення педагогічних дисциплін у закладі вищої освіти, зокрема, мотиваційно-ціннісний, змістовий, процесуальний, інформаційний та творчий.

Таким чином, оволодіння студентами фізкультурно-оздоровчою компетентністю дозволяє в майбутньому у процесі професійної діяльності обирати оптимальні стратегії фізкультурно-оздоровчої та спортивно-масової роботи, нетрадиційні підходи, інноваційні методи й форми роботи, інформаційно-комунікаційні засоби з метою підвищення мотивації учнів до активної фізкультурної діяльності та ведення здорового способу життя. 
Перспективи подальших досліджень вбачаємо в детальному аналізі, узагальненні та виокремленні основних методик формування фізкультурно-оздоровчої компетентності в процесі вивчення педагогічних дисциплін у розвинених європейських країнах з метою їх імплементації у вітчизняних педагогічних закладах вищої освіти.

\section{ЛІТЕРАТУРА}

Безверхня, Г. В. (2003). Мотивація до занять фізичною культурою і спортом школярів 5-11 класів (дис. ... канд. наук з фізичного виховання і спорту: 24.00.02). Умань (Bezverkhnia, H. V. (2003). M otivation for physical education and sports of students of 5-11 grades (PhD thesis). Uman).

Гуменюк, С. (2015). Актуальність використання засобів інноваційних технологій у фаховій підготовці майбутніх учителів фізичної культури. Фізичне виховання, cпорт $i$ культура здоров'я у сучасному суспільстві. (Humeniuk, S. (2015). The relevance of the use of innovative technologies in the professional training of future physical culture teachers. Physical education, sports and health culture in modern society).

Драч, І. І. (2014). зміст і технологія підготовки фахівців з педагогіки вищої школи за заочною формою навчання в умовах ЄКТСОНП, адаптованої до національної вищої освіти та до специфіки заочної форми навчання. Теоретичні та методичні засади управління підготовкою фрахівців з педагогіки вищої школи на основі компетентнісного підходу в межах європейської кредитно-трансферної системи організачії навчального прочесу. К.: ТОВ «Альфа-Реклама», сс. 201-224 (Drach, I. I. (2014). Content and technology of training specialists in pedagogy of higher school at correspondence form in ECTSEPO, adapted to national higher education and to the specifics of the correspondence form of education. Theoretical and methodological principles of the management training of specialists in higher school pedagogy based on the competence approach within the framework of the European credit transfer system of the educational process organization. K.: Alfa-Advertising LLC, pp. 201-224).

Іваній, І. (2013). Компетентнісний підхід до професійної підготовки вчителя фізичної культури. Фіз. виховання, спорт і культура здоров'я в сучасному суспільстві: зб. наук. пр. Східноєвроп. Нац. ун-ту ім. Лесі Українки. Луцьк, 21, $43-48$ (Ivanii, I. (2013). Competence approach to professional training of a physical culture teacher. Phys. education, sport and health culture in modern society: Coll. of scient. works of the East-European State University named after Lesia Ukrainka. Lutsk, 21, 4348).

Климов, Е. А. (1996). Психология профессионала. М.: ИПП; Воронеж: НПО МОдэК (Klimov, E. A. (1996). Professional Psychology. M.: IPP; Voronezh).

Компетентнісний підхід у сучасній освіті: світовий досвід та українські перспективи (2004). K.: «K.I.C.». (Competence Approach in Modern Education: World Experience and Ukrainian Perspectives (2004). K.: «K.I.S»).

Кострікін, О. В. (2013). Формування та розвиток професійних якостей особистості майбутніх керівників засобами тренінгу в навчально-виховному процесі ВН3. Проблеми сучасної психології, 21, 268-278 (Kostrikin, 0. V. (2013). Formation and development of professional qualities of the personality of future managers by means of training in the educational process of universities. Problems of Modern Psychology, 21, 268-278).

Кравченко, В. М. (2016). Стратегія змін і розвитку вищої освіти в підготовці науковопедагогічних працівників. Педагогіка формування творчої особистості у вищій і загальноосвітній школах, 47 (100), 283-293 (Kravchenko, V. М. (2016). The strategy of change and development of higher education in the training of teaching 
staff. Pedagogy of Formation of a Creative Personality in Higher and General Education Schools, 47 (100), 283-293).

Методичні рекомендації щодо розроблення стандартів вищої освіти (2016). Затверджено наказом Міністерства освіти і науки України від «01» червня 2016 № 600. URL: http://osvita.ua/doc/files/news/515/51506/Recom.doc. (Guidelines for the development of higher education standards (2016). Approved by the Order of the $M$ inistry of Education and Science of Ukraine of June 01, 2016 No. 600).

Омельяненко, І. О. (2006). Теоретичні основи компетентнісного підходу щодо підготовки вчителя фізичної культури. Професійні компетенції та компетентності вчителя: Матеріали регіонального науково-практичного семінару. Тернопіль: Вид-во ТнПу ім. В. Гнатюка, сc. 116-119 (Omelianenko, I. 0. (2006). Theoretical foundations of a competence approach to the training of physical culture teachers. Teacher's professional competences: Materials of a regional scientific-practical seminar. Ternopil: Issue of TNPU named after V. Hnatyuk, pp. 116-119).

Онопрієнко, О. В. (2009). Формування базових профресійних компетентностей майбутнього вчителя фізичної культури у процесі вивчення фрахових дисциплін (автореф. дис. ... канд. пед. наук: 13.00.04) (Onopriienko, O. V. (2009). Formation of basic professional competences of the future physical culture teacher in the process of learning professional disciplines (PhD thesis abstract).

Процко, Х. В. (2009). Проблема визначення компетентностей вчителя технологій для здійснення ефективної педагогічної діяльності. Педагогіка вищої та середньої школи, 25, 39-46 (Protsko, H. V. (2009). The problem of determining the competences of a technology teacher to carry out effective pedagogical activities. Pedagogy of higher and secondary school, 25, 39-46).

Сидоренко, В. В. (2017). Розвиток професійної компетентності сучасного педагога в умовах відкритої освіти: кластерний аналіз. Професійна компетентність педагога в умовах оновленого змісту освіти та вимог ринку праці: III регіональна науково-практична конференція. Вінниця: Вінницька міська друкарня, сc. 8-17 (Sydorenko, V. V. (2017). Development of professional competence of a modern teacher in the conditions of open education: a cluster analysis. Teacher's professional competence in the terms of updated education content and labor market requirements: III regional scientific-practical conference. Vinnytsia: Vinnytsia City Printing House, pp. 8-17).

Скворцова, С. О. (2011). Професійна компетентність вчителя: модель формування. Науковий часопис НПУ імені М. П. Драгоманова. Серія 16. Творча особистість учителя: проблеми теорії і практики: збірник наукових праць. Вип. 14 (24), 59-66 (Skvortsova, S. O. (2011). Teacher's professional competence: a model of formation. Scientific journal of the NPU named after M.P. Dragomanov. Series 16. The creative personality of the teacher: problems of theory and practice, Issue 14 (24), 59-66).

Сущенко, Л. П. (2003). Профресійна підготовка майбутніх фіхівців фізичного виховання ma спорту (теоретико-методологічний аспект) (Sushchenko, L. P. (2003). Professional training of future specialists in physical education and sport (theoretical and methodological aspect)).

\section{PEЗЮME}

Чернякова Жанна. Формирование физкультурно-оздоровительной компетентности будущих учителей физической культуры в процессе изучения педагогических дисциплин.

В статье представлен теоретический анализ различных видов компетентностей в составе физкультурно-оздоровительной компетентности 
учителя физической культуры в зависимости от типов профессиональной деятельности, сферы проявления и реализации определенных видов компетентности, функций профессиональной деятельности. Охарактеризованы три уровня компетентностей с использованием дескрипторов «Национальной рамки квалификаций» («знания», «умения», «коммуникация» и «автономность и ответственность»): интегральные, общие и специальные. Конкретизированы компоненты структуры физкультурно-оздоровительной компетентности будущих учителей физической культуры в процессе изучения педагогических дисциплин в учреждении высшего образования, в частности, мотивационно-ценностный, содержательный, процессуальный, инфрормационный и творческий.

Ключевые слова: физкультурно-оздоровительная компетентность, учителя физической культуры, интегральные, общие и специальные компетентности, педагогические дисциплины, учреждение высшего образования.

\section{SUMMARY}

Chemyakova Zhamna. Formation of physical and healthcare competence of future physical culture teachers in the process of studying pedagogical disciplines.

The article presents the theoretical analysis of different types of competences within the physical and healthcare competence of future physical education teachers in the process of studying pedagogical disciplines in higher education institutions.

The purpose of the study is a theoretical analysis and characterization of the components of the structure of physical and healthcare competence of future physical culture teachers in the process of studying pedagogical disciplines in higher education institutions.

The stated purpose of the study has led to the choice of a set of interrelated methods, in particular - theoretical: theoretical analysis of scientific literature and normative documents, synthesis, comparison, generalization and systematization of the obtained data in order to determine the content and structure of physical and healthcare competence of future physical culture teachers in the process of studying pedagogical disciplines.

In the process of teaching pedagogical disciplines, it is necessary to form the physical and healthcare competence of future physical culture teachers in order to perform their own professional activity. The author has mentioned several urgent problems of training future physical culture teachers, in particular, vocational-pedagogical training, psychological and pedagogical bases of mastery of the teacher, teaching of separate pedagogical disciplines in the structure of training future physical culture teachers, preparing future teachers for creative search activities; use of information and communication technologies; use of various innovative methods, training tools in the process of professional training.

The author has determined three levels of competences, using the descriptors of "National Qualifications Framework" ("knowledge", "skills", "communication" and "autonomy and responsibility"): integrated, general and specific. On this basis the components of the structure of physical and healthcare competence of future physical culture teachers in the process of studying pedagogical disciplines in higher education institution, in particular, motivational-value, content, procedural, information and creative are specified and characterized.

The study does not exhaust all aspects of the above problem. The prospects for further research can be seen in the detailed analysis, generalization and identification of the basic methods of formation of physical and healthcare competence in the process of studying pedagogical disciplines in the developed European countries for the purpose of their implementation in the national pedagogical institutions of higher education.

Key words physical and healthcare competence, physical culture teachers, integral, general and special competences, pedagogical disciplines, higher education institution. 